Article

\title{
Beach Response to Wave Forcing from Event to Inter-Annual Time Scales at Grand Popo, Benin (Gulf of Guinea)
}

\author{
Grégoire Abessolo Ondoa 1,2,*, Frédéric Bonou 2,3,4, Folly Serge Tomety 2,3,4, \\ Yves du Penhoat ${ }^{2,3,4}$, Clément Perret ${ }^{2,3,4}$, Cossi Georges Epiphane Degbe ${ }^{3}$ and Rafael Almar ${ }^{2}$ \\ 1 Fishery Resources Laboratory, University of Douala, BP 2701 Douala, Cameroon \\ 2 LEGOS (Université Paul Sabatier de Toulouse/CNRS/CNES/IRD), 31400 Toulouse, France; \\ fredericbonou@yahoo.fr (F.B.); sertom1@hotmail.fr (F.S.T.); yves.du-penhoat@ird.fr (Y.d.P.); \\ clement.perret@outlook.com (C.P.); rafael.almar@ird.fr (R.A.) \\ 3 Institut de Recherches Halieutiques et Océanologiques du Bénin, 03 BP 1665 Cotonou, Benin; \\ gdegbe@yahoo.fr \\ 4 International Chair in Mathematical Physics and Applications/Unesco Chair, University of Abomey-Calavi, \\ 01 BP 526 Cotonou, Benin \\ * Correspondence: gregsolo55@yahoo.fr; Tel.: +237-699-76-73-34
}

Received: 31 March 2017; Accepted: 16 June 2017; Published: 21 June 2017

\begin{abstract}
This paper assesses the morphological storm-event impact, seasonal cycles, trends of wave forcing, and beach's response at the coastal area of Grand Popo, Benin. Three and a half years' worth of data were collected from 2013 to 2016, using a video system calibrated with field data collected during a 10 day experiment. A comparison was carried out with Wavewatch III IOWAGA wave hindcast data. The along-shore-averaged shoreline position exhibited a seasonal pattern, which was related more to the average wave height than the average storm intensity. Storms occur in austral winter (June, July, August, and September). Based on 12 storms, the results revealed that the average storm duration was 1.6 days, with a mean erosion of $3.1 \mathrm{~m}$. The average post-storm beach recovery duration was 15 days, and the average recovery rate was $0.4 \mathrm{~m} /$ day. The impact of storms was more or less amplified depending on the eroding and accreting periods of the wave climate. There was an inter-annual eroding trend of about $-1.6 \mathrm{~m} /$ year, but the causes of this trend could not be explained.
\end{abstract}

Keywords: shoreline; waves forcing; storms; resilience; post-storm recovery; Bight of Benin; seasonal cycle; trend

\section{Introduction}

The coastal zone of West Africa is under increasing pressure of overpopulation, as it is a zone of economic interest. Human settlements and livelihood activities have been developing on the shores of the Atlantic Ocean, where the beach evolution varies according to a wide range of different temporal and spatial scales. In this region, beaches are microtidal and swell-dominated environments, where waves and tides are the main drivers of nearshore dynamics [1]. Several findings suggest that along wave-dominated coastlines, regionally-varying wave climates will have an increasing impact on the shoreline in the coming decades, and cannot be ignored in forecasting shoreline variability [2-4]. This highly dynamic behaviour is essentially due to the fact that sandy coasts can undergo adjustments in form and processes, which can change rapidly. Periods of accretion and erosion are generally associated with low- and high-energy wave conditions, respectively, but they also exhibit strong site-specific variations [5]. For many coastal regions, both sea-level rise and changes in the storm-wave climate would result in coastal erosion and an increased frequency with a high intensity of coastal flooding. Storm-events represent a major factor of modulating short- and medium-term morphological 
evolutions of many sandy shorelines. In the event of changing storm regimes associated with climate change [6], it is important to understand the potential effects of storms on beaches, and how they recover after these high-energy events. Many studies have been carried out on assessing the impact of storms, beaches' responses, and post-storm morphological adjustments in storm-dominated coastlines [6-12]. Managing erosion-induced problems will depend on the resilience of the beach to extreme events, and universal threshold conditions are not likely to be found [5]. Establishing storm thresholds is difficult, especially because they are generally site-specific [11,13]; this is as well as the beach recovery period [7], which has not yet been clearly addressed in the literature. Available literature regarding beaches' responses to storms on tropical microtidal coastlines and the potential impacts of climate change remains scarce.

Along the wave-dominated coastlines of the Gulf of Guinea, the influence of South Atlantic high-energy swells drives strong, eastward longshore sediment transport [14,15]. This littoral drift in the Bight of Benin is one of the largest in the world, with estimations of approximatively $400,000-1,000,000 \mathrm{~m}^{3} /$ year [16]. This transport is mostly driven by swell waves due to the Southern Annular Mode (SAM), rather than wind waves due to the Inter-Tropical Convergence Zone (ITCZ) [15]. This equatorial fluctuation presents a large seasonal and inter-annual variability as well as wave climate [14]. This implies a high seasonal variability in the beaches' responses to equatorial Atlantic forcing, given that seasonal processes dominate the shoreline changes due to seasonal variations of the wave height at several specific sites [5,17]. These findings need to be confirmed, but few measurements are available on the high-frequency evolution of shoreline and beach states in the West and Central African regions.

This study assesses different time scales of beach responses to wave forcing at Grand Popo Coast, Benin, using video-derived shoreline and wave evolution data over a 3.5 year observation period (February 2013 to August 2016). We first investigate an average beach response during and after storm-events. Secondly, we evaluate the impact of storm durations and recurrence with seasonal variability. And finally, we estimate the inter-annual trends.

\section{Data and Methods}

\subsection{Study Area}

Located in the Gulf of Guinea, Benin, near the border with Togo, Grand Popo Beach is an ocean-open, sandy stretch of coast facing the South Atlantic Ocean [18]. The beach is far enough from the influence of the major cities: Cotonou ( $80 \mathrm{~km}$ away), and Lome (60 km away). In the last three years, some fields of groynes have been constructed near the town of Anèho, $20 \mathrm{~km}$ updrift [19] (see Figure $1 b)$.

The beach dynamics are dominated by the influence of oblique waves (South/Southwest) of moderate energy (mean significant wave height $H s=1.36 \mathrm{~m}$; mean peak period $T p=9.4 \mathrm{~s}$ ). The longshore sediment transport is primarily driven by swell waves (South/Southwest and South/Southeast) generated in the Southern Hemisphere trade-wind region (30-35 $\mathrm{S}$ and $45-60^{\circ} \mathrm{S}$ ), rather than wind waves (Southwest) generated locally in the Gulf of Guinea [14-16,20], as shown in Figure 1a. Tides are semi-diurnal with a microtidal range from 0.8 to $1.8 \mathrm{~m}$ for neap and spring tides, respectively. The sediment size is medium-to-coarse: 0.4 to $1 \mathrm{~mm}$ (median grain size $D 50=0.6 \mathrm{~mm}$ ). Grand Popo Beach is an intermediate low tide terrace (LTT) to reflective beach $[14,18,20]$, according to the classification proposed in [21]. 


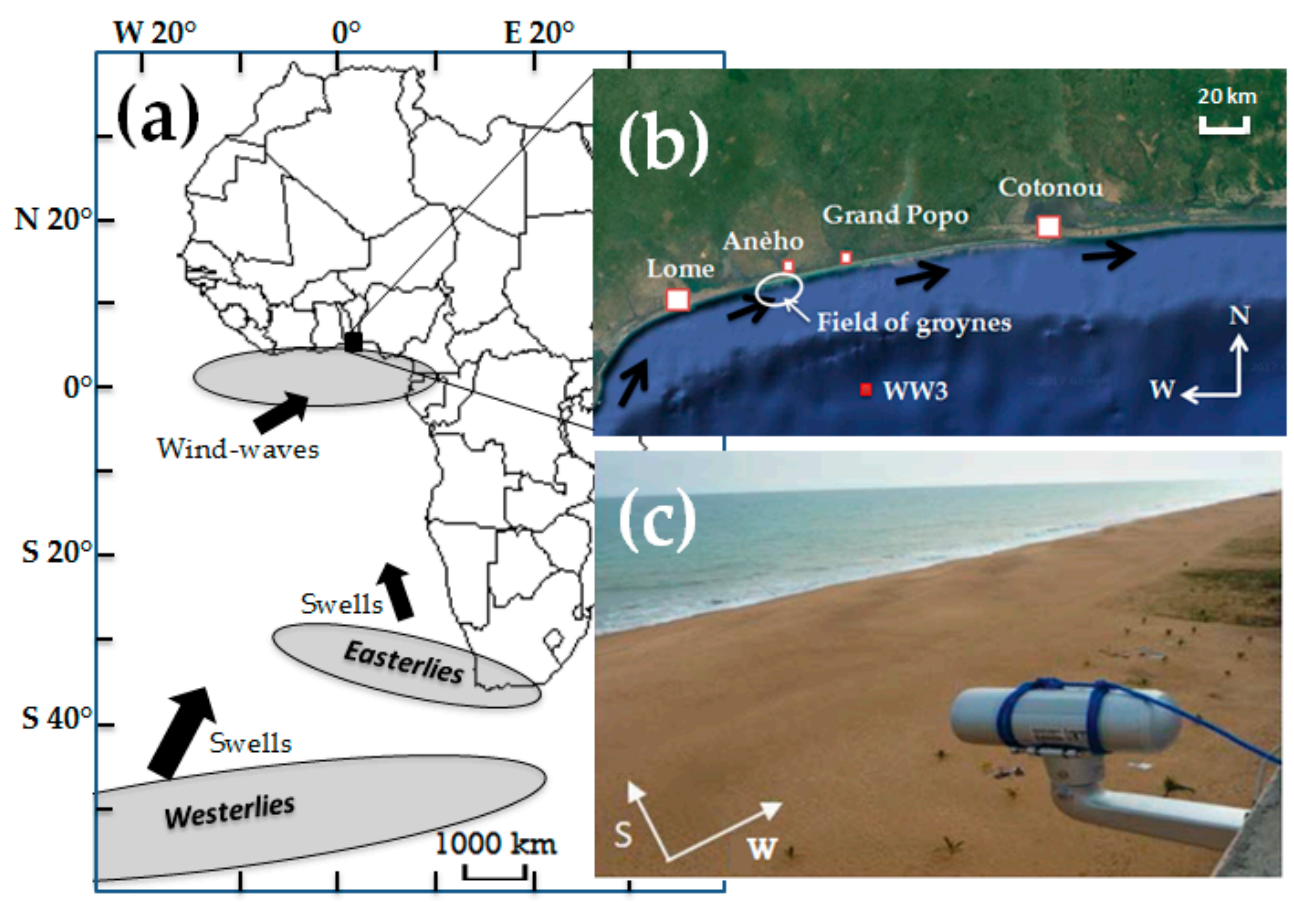

Figure 1. Study site: (a) The regions of major generations of swells and wind waves impinging on the Gulf of Guinea are indicated by grey ovals, and their major directions of propagation by the black arrows. (b) Focus in the Bight of Benin, with major cities of Cotonou and Lomé. Black arrows represent the longshore sediment transport directions. The red point $\left(2.0^{\circ} \mathrm{E}, 5.5^{\circ} \mathrm{N}\right)$ gives the location of the WW3 model output. (c) Permanent video camera on a $15 \mathrm{~m}$ high semaphore at Grand Popo Beach, Benin.

\subsection{Video System and Data}

In February 2013, a low-cost video system was installed on the top of a tower of the Navy Forces of Benin in Grand Popo, about $70 \mathrm{~m}$ from the shoreline [22]. The system was composed of a VIVOTEK IP 7361 camera $(1600 \times 728$ pixels $)$, which collected data continuously at $2 \mathrm{~Hz}$. An on-site computer processed the raw images and stored three types of secondary images every 15 min: snapshots, cross-shore time-stacks, and $15 \mathrm{~min}$ time exposure (or timex) images (Figure 2) [22]. Twenty ground control points were taken with GPS to process image geo-rectification [23], by applying the method of direct linear transformation [24]. This consists of a matrix, which gives the relation between image pixels and control points by taking into account the position of the camera and the correction due to the camera lens distortion [25].

Several recent methods were used to extract hydrodynamic and morphologic parameters. $H s$ video estimations were obtained from the time-stack images [26]. Following the wave signature induced by breaking, wave heights were detected from the pixel intensity threshold Ipix $=40$. The intensity of breaking pixels was significantly larger (Ipix $>80)$ than that of non-breaking pixels (Ipix 10). The pixel intensity peak, which appeared at the wave crests, was calculated by the standard deviation $\delta$ of the pixel intensity of each time series. The width of the peak of $\delta$ marked the horizontal projection of the wave face covered by the roller $(L)$, which was subsequently projected into the vertical direction for a simple rough estimation: $H_{b}=L \cdot \tan (\beta)$, where $\beta$ was the camera view angle. The fact that the wave-front slope $\left(\alpha_{b}\right)$ at breaking differed significantly from the vertical direction was taken into account. The common value $\alpha_{b} \approx 30^{\circ}$ is used as a breaking criterion in numerical breaking parameterizations, according to [26]. The wave height could therefore be estimated from the equation [26]:

$$
H_{b}=(L-\operatorname{Cor}) \tan (\beta)
$$


Cor being a geometrical correction defined as [26]:

$$
\text { Cor }=\frac{L}{\tan \left(\alpha_{b}\right)} \tan (\beta)
$$

The mean wave period $T_{m}$ was computed from the offshore pixel intensity time series using the mean zero-crossing method on the time-stack images [27]. Wave direction was estimated from the snapshots and $15 \mathrm{~min}$ averaged images. The technique consisted of, firstly, subtracting the average image from the snapshot (removing the background, which does not move); secondly, highlighting the wave crests (the time-varying part); then rectifying on a regular grid; and finally, recovering the angle of the crest of the waves by the Radon transform [28].
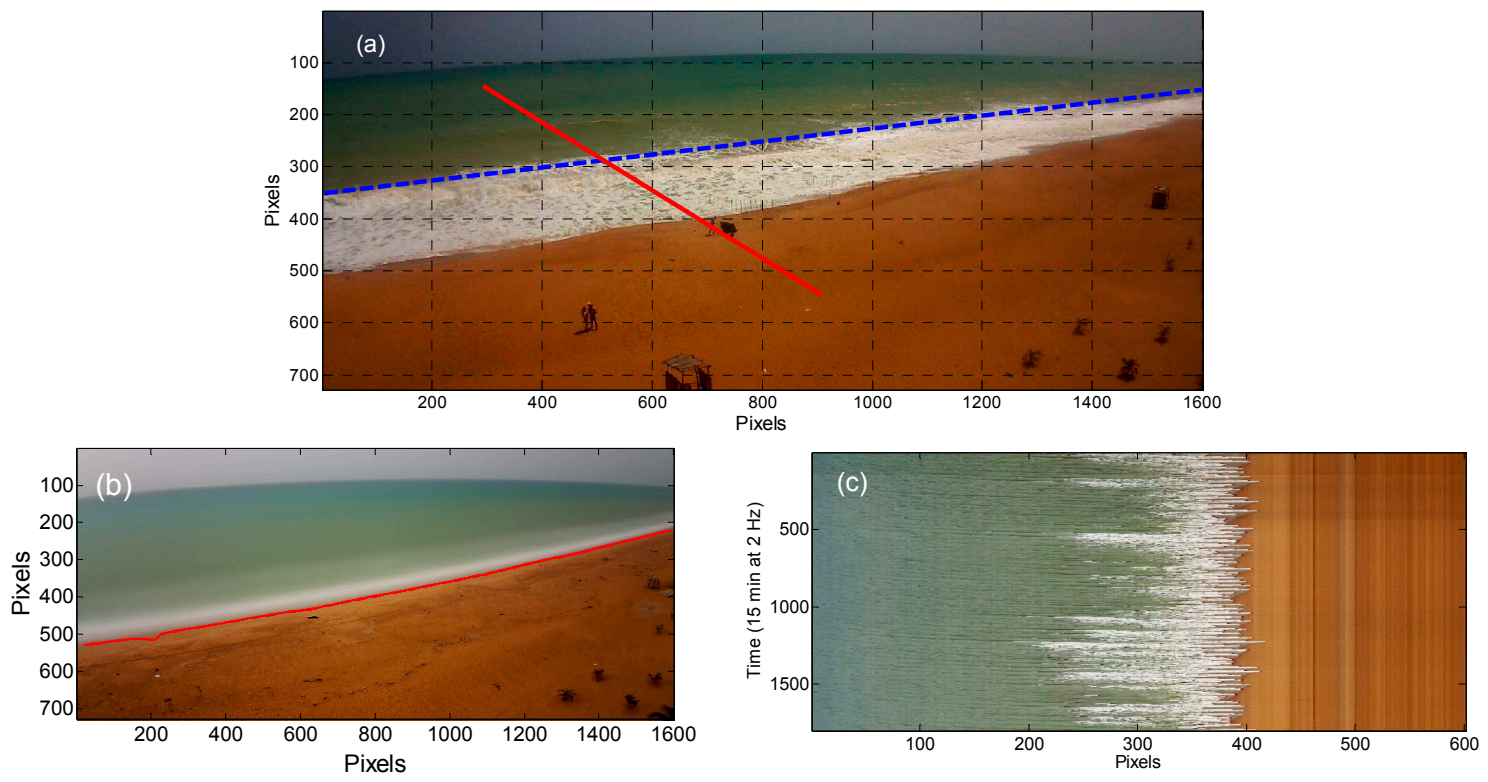

Figure 2. Video image types: (a) Snapshot with cross-shore time-stack profile as a red line, and along-shore time-stack profile as a blue dashed line. (b) 15 min averaged image; shoreline is shown as a red line. (c) Cross-shore time-stacked image (vertical is time: $15 \mathrm{~min}$ at $2 \mathrm{~Hz}$ ).

A 10 day field experiment was conducted at Grand Popo Beach, Benin, in March 2014 [22]. The measurements included both topographic and bathymetric morphological surveys with differential GPS (DGPS) and bathymetric sonar, while offshore forcing (waves and tide) was characterized using an Acoustic Doppler Current Profiler (ADCP) moored at a $10 \mathrm{~m}$ depth. Hs video data were regressed with 10 days of ACDP field data, with an acceptable root-mean-square error (RMSE) of $0.14 \mathrm{~m}$ [18].

Due to technical malfunctions in the video acquisition system, missing video data could be estimated with linear regression between existing video data and Wavewatch III (WW3), model version 4.10 (IOWAGA wave hindcast database [29]) output at the nearest available point, $2.0^{\circ} \mathrm{E}$, $5.5^{\circ} \mathrm{N}$ (Figure $1 \mathrm{~b}$ ), propagated to breakpoint using an empirical predictor formula [30]. This formula was used in a recent study [15] focusing on wave climate variability in the Bight of Benin. This formula directly provides the breaking wave height $h_{b}$ and angle $\theta_{b}$, given deep water wave height $h_{0}$, period $T$, and direction $\theta_{0}$ :

$$
\begin{gathered}
h_{b}=\lambda \cdot C^{2} / g \\
\theta_{b}=a \sin \left(\sin \left(\theta_{0}\right) \cdot \sqrt{\lambda}\right)
\end{gathered}
$$

with a correction factor $\lambda$ computed by:

$$
\lambda=\Delta \cdot \lambda_{a}
$$


where:

$$
\begin{gathered}
\Delta=1+0.1649 \xi+0.5948 \xi^{2}-1.6787 \xi^{3}+2.8573 \xi^{4} \\
\xi=\lambda_{a} \cdot\left(\sin \theta_{0}\right)^{2} \\
\lambda_{a}=\left[\cos \left(\theta_{0}\right) / \varphi\right]^{\frac{2}{5}} \\
\varphi=\left(\frac{C}{\sqrt{g h_{b}}}\right)^{4}\left(\frac{C}{C_{g}}\right) \gamma^{2}
\end{gathered}
$$

where the phase celerity is given by $C=1.6 T$, group celerity $C_{g}=\frac{C}{2}$ and breaker depth index $\gamma=0.78$.

The shoreline location was calculated from timex images as the maximum gradient in the ratio red/green-blue [31]. Beach pixels display high red-channel values and low green values, whereas water pixels exhibit strong green-channel values and low red values [25,32]. The ratio red/green-blue was computed for all pixels and its local minimum stood for the transition between water and beach, namely, the shoreline. The overall error in video detection of the shoreline location owing to water level uncertainties, due to wave breaking or atmospheric pressure variations, or incorrect shoreline detection, was about $0.5 \mathrm{~m}$ [12]. Shoreline migration was estimated via the along-shore-averaged location $\langle X\rangle$ to reduce error data due to the along-shore-digitized shoreline. Determination of the intertidal beach profile and beach slope involved the delineation of the shoreline at different tidal levels [32], and interpolation between daily low and high tides. Tidal levels for the study period 2013-2016 were extracted from the WXTide32 model, version 4.7. As there was no tide gauge at the study site, the tidal subordinate at Lomé, Togo $\left(1^{\circ} 14^{\prime} \mathrm{E}, 6^{\circ} 07^{\prime} \mathrm{N}\right)$ was referred to the nearest tide gauge station, Takoradi, Ghana $(\sim 350 \mathrm{~km})$. The root-mean-square and mean errors in the intertidal profile computed between 7 day DGPS (Grand Popo experiment, 2014) and video data were 0.28 and $0.23 \mathrm{~m}$, respectively [18].

\subsection{Event Scale: Storms}

The definition of storm-event is site-specific [5,9], and the Hs threshold used to define storm conditions or extreme events is selected to produce clear and identifiable storm-events. Three-hourly $H$ s time series were used, and the $5 \%$ exceedance probability of the wave height time series over the study period $\left(H_{S_{5 \%}}=1.85 \mathrm{~m}\right)$ was considered as the threshold for storm-events. A single storm is defined as a continuous period of $H s$ exceeding this threshold and lasting at least one tidal cycle $(12 \mathrm{~h})$, following [5,12]. The overall impact of storm-events is assessed through the daily-averaging maximum shoreline moving during the storm. Storm intensity $I\left(\mathrm{~m}^{2} \cdot \mathrm{h}\right)$ is computed as the integration of time-varying $H s$ over the storm duration:

$$
I=\int_{t_{1}}^{t_{2}} H_{S}(t)^{2} \cdot d t
$$

where $t_{1}$ and $t_{2}$ are times corresponding to the beginning and the end of the storm [12].

There are several ways to define the recovery duration after each storm. It can be defined as the time taken by the nearshore morphology to evolve from a post-storm state (e.g., dissipative/longshore bar and trough) to its modal state (i.e., the most frequently occurring beach state, e.g., rhythmic bar and beach or transverse bar and rip) [9-11]. In this study, the time duration taken to reach the first maximum recovery value of the along-shore-averaged shoreline location $<X>$ after each storm was accepted as the recovery duration $[10,12]$. This duration referred to the post-storm period of continuous accretion towards its equilibrium pre-storm state (Tr), and did not depend on any forcing parameter. The overall recovery duration for the study period was computed as the time for daily-averaging post-storm evolution of continuous accretion [5]. 


\subsection{Seasonal Signal and Trends}

To obtain the seasonal signal, monthly nearshore estimations were computed. The test of Mann Kendall was used to check if the time series showed substantial trends [33]. The null hypothesis of trend absence in a time series was tested, against the alternative of having a trend. Each time series was reorganized as a matrix $M_{i j}$ where $1 \leq i \leq N_{y}$ with $N_{y}$ representing the number of years of video observation, and $1 \leq j \leq 12$. The seasonal signal $S_{j}$ was obtained as follows:

$$
S_{j}=\frac{1}{N_{y}} \cdot \sum_{i=1}^{N_{y}} M_{i j}
$$

The monthly residual or anomaly signal $R_{i j}$ of each parameter was estimated by removing the seasonal monthly value from each monthly-averaged value computed over the three and a half years. The annual anomaly or trend $R_{a}$ was computed by averaging monthly anomaly values $R_{i j}$.

\section{Results}

\subsection{Hydrodynamic and Morphological Variability}

Figure 3a-c provides an overview of monthly video and WW3 data [29] over the study period. The same $H$ s seasonality for the two sets of data was observed (Figure 3a), with more energetic waves during the April-October period and less energetic waves during the November-March period. These observations are consistent with the wave climate of the area because of northward migration, by a few degrees, of the wave-generating zone in the high latitudes of the South Atlantic $\left(\sim 40^{\circ}\right.$ to $\left.60^{\circ} \mathrm{S}\right)$ during the summer period $[14,15]$. Table 1 gives correlations and errors between the WW3 video and model data on the time series of $\mathrm{Hs}, \mathrm{Tm}$, and the wave direction. There is strong correlation between the two time series of $H s\left(R^{2}=0.80\right)$. Direction and Tm are less correlated $\left(R^{2}=0.44\right.$ and $R^{2}=0.19$; Figure $3 b, c)$, with a low observed variability.

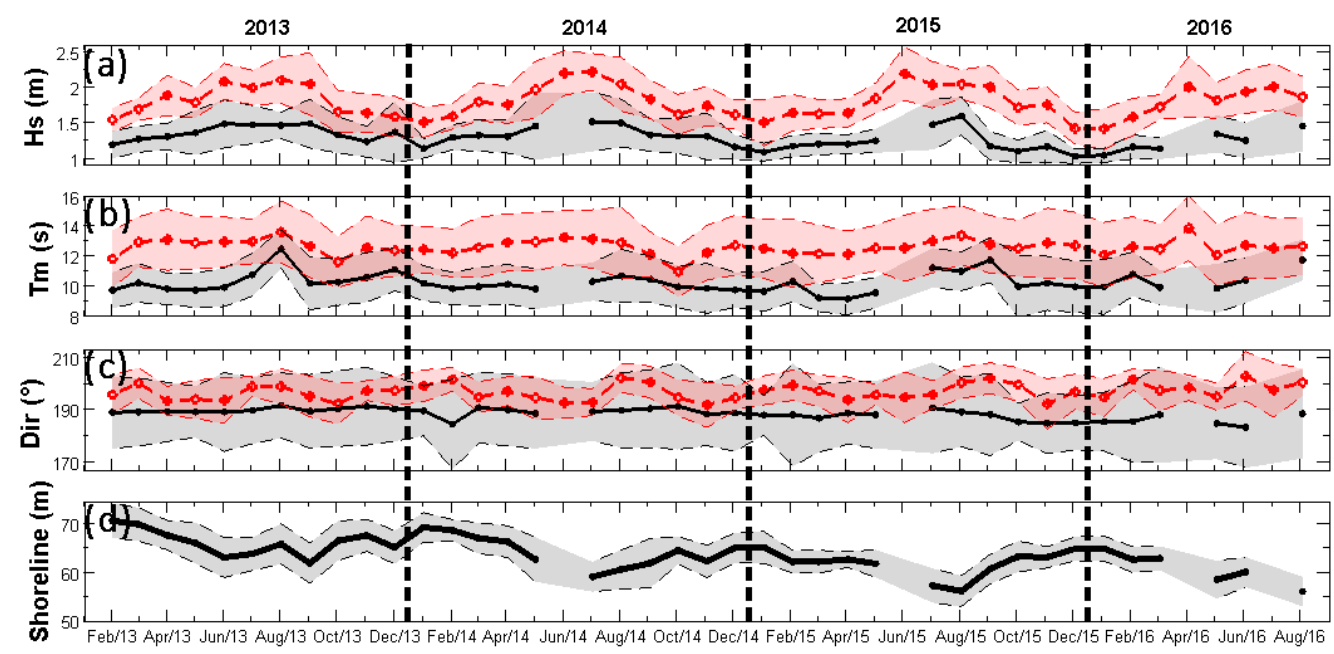

Figure 3. Monthly-averaged video estimates (black) and Wavewatch III data (red): (a) wave significant height $\mathrm{Hs}$; (b) wave mean period Tm; (c) wave direction Dir; and (d) shoreline location. Shaded zones stand for day-to-day dispersion (standard deviation).

It should be noted here that the IOWAGA WW3 ocean wave hindcast had not been assimilated with any observations (satellite or buoy). For the previous versions of WW3, random averaged errors between $H s$ model outputs (WW3) and satellite data ranged from 0.3 to $0.4 \mathrm{~m}$ for low wave heights $(<2 \mathrm{~m})$, and $0.15 \mathrm{~m}$ for higher waves [34]. An improvement was made on the recent version used in this work, integrating new parameterizations for the wind-sea and wave dissipation. However, the 
normalized RMSE for $H s$ remained $\sim 20 \%$, compared to the satellite data in our study area, with biases of more than $0.1 \mathrm{~m}$ [29]. This was consistent with the overestimation observed in the model outputs (Figure 3), which were likely amplified due to local unresolved effects of bathymetry for the wave propagation from deep water to breaking point. However, WW3 results were improved even more from linear regression correction than from bias correction, as shown in [35]. Gaps in Hs video data could therefore be estimated using a linear regression between the two sets of data.

Table 1. Comparison of daily hydrodynamic video data and WW3 model outputs. WW3 data were propagated from deep water to breakpoint using an empirical direct formula [30]. The root-mean-square error (RMSE) and the mean error (ME) were computed between the two sets of data.

\begin{tabular}{cccc}
\hline Video-WW3 & Hs $(\mathbf{m})$ & $\mathbf{T m}(\mathbf{s})$ & $\operatorname{Dir}\left(^{\circ}\right)$ \\
\hline Correlation & 0.8 & 0.4 & 0.2 \\
RMSE & 0.3 & 2.4 & 9.4 \\
ME & 0.3 & 2.3 & 8.5 \\
\hline
\end{tabular}

\subsection{Storms and Morphological Impact}

\subsubsection{Detection and Statistics of Individual Storms}

Thirty-two storms were identified over the study period (Figure 4a). The mean peak storm wave height was $2.05 \mathrm{~m}$ (standard deviation $\sigma=0.05 \mathrm{~m}$ ) and the mean wave height throughout the storms was $1.99 \mathrm{~m}(\sigma=0.12 \mathrm{~m})$. The average duration of a storm was 1.8 days and storms were recorded from April to September, corresponding to austral winter. With the threshold value of $H_{5_{5 \%}}=1.85 \mathrm{~m}$, no storm with a duration longer than $12 \mathrm{~h}$ was recorded from the November to March period, due to less energetic wave conditions. Only 12 storms (average duration of 1.6 days) were further considered for analyses of shoreline responses due to gaps in shoreline data. Individual storms resulted in a wide range of shoreline impacts (Figure 4b), from no change on 2 July 2013 (1 day storm), to significant erosion $(-8.7 \mathrm{~m})$ during a 4 day storm (21-25 September 2013). The maximum number of storm-events was recorded in July. In 2014 for example, 12 storms were counted, with four in July. The strongest storm impacts were recorded at the end of austral fall (in May) with an average onshore migration of $-3.7 \mathrm{~m}$ during a storm of less than 1 day. This impact decreased with the increase of storm numbers until the beginning of austral winter (June and July).
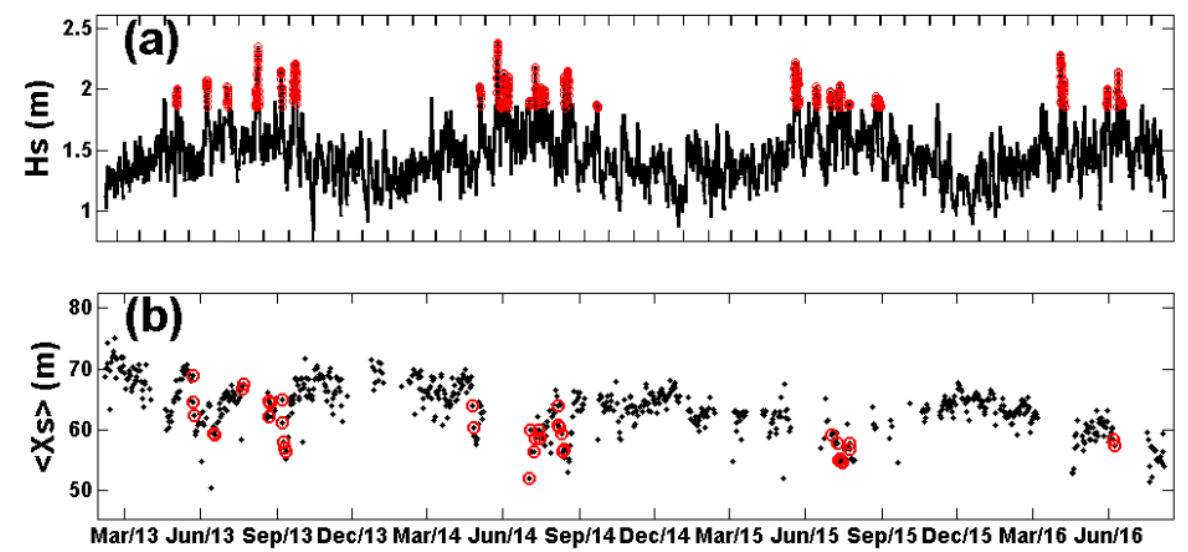

Figure 4. Time series of: (a) significant wave height, and (b) along-shore-averaged location $<X s>$ from the tower of camera location. Storm periods are marked in red.

\subsubsection{Beach Response to Storms and Resilience}

Figure 5 shows an ensemble-averaged analysis of the shoreline evolution during the storm and post-storm recovery period, with this period referring to the post-storm period of continuous accretion, 
at the end of which the beach was assumed to be stabilized $[5,9,12]$. The day " 0 " stands for the beginning of the storm, according to the $5 \%$ exceedance $(1.85 \mathrm{~m})$ of $H s$. The average storm intensity was $155 \mathrm{~m}^{2} \cdot \mathrm{h}$ and induced an average beach erosion of $3.1 \mathrm{~m}$. After the end of the storm, the beach attempted to recover during a continuous accretive phase: the shoreline moved offshore $(0.46 \mathrm{~m} /$ day $)$ and the time needed to reach stabilization was $\sim 15$ days. This time was considered as the post-storm recovery duration $T r$.
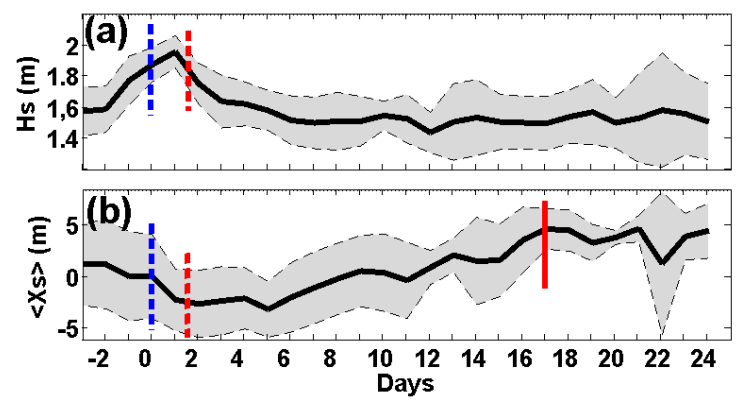

Figure 5. Ensemble-averaged evolution during the storm and post-storm recovery period for: (a) $H s$, and $(\mathbf{b})$ shoreline location $\langle X s\rangle$. Blue dashed lines stand for the beginning of the averaged-storm, red dashed lines for the end of the storm (1.6 day storm duration), and the solid red line stands for the post-storm recovery duration for beach stabilization (15 days).

\subsection{Seasonal Cycle}

Figures 6 and 7 present the seasonal cycle of several monthly nearshore forcing parameters and beach morphology. The maximum monthly-averaged $\mathrm{Hs}(1.51 \mathrm{~m})$ was obtained in July, corresponding to the maximum monthly-averaged wave flux $(15400 \mathrm{~J} / \mathrm{m} \cdot \mathrm{s})$. The seasonal pattern was highlighted in the along-shore-averaged shoreline position, which was strongly correlated to the monthly $H s$ seasonal cycle $\left(R^{2}=-0.94\right)$, and in contrast, less correlated to the monthly-averaged beach slope $\left(R^{2}=-0.25\right)$. The maximum beach slope was $0.14 \mathrm{rad}$ at the end of April. For the 32 identified storms, the greatest number of storms was recorded in July, but these were shorter (average duration of 1.34 days), leading to a lesser average intensity compared to the other months. Figure $6 a, d$ and Figure $7 a$ show that the beach response (shoreline location) was most related to the monthly-averaged $H s$ rather than the intensity of storm-events.
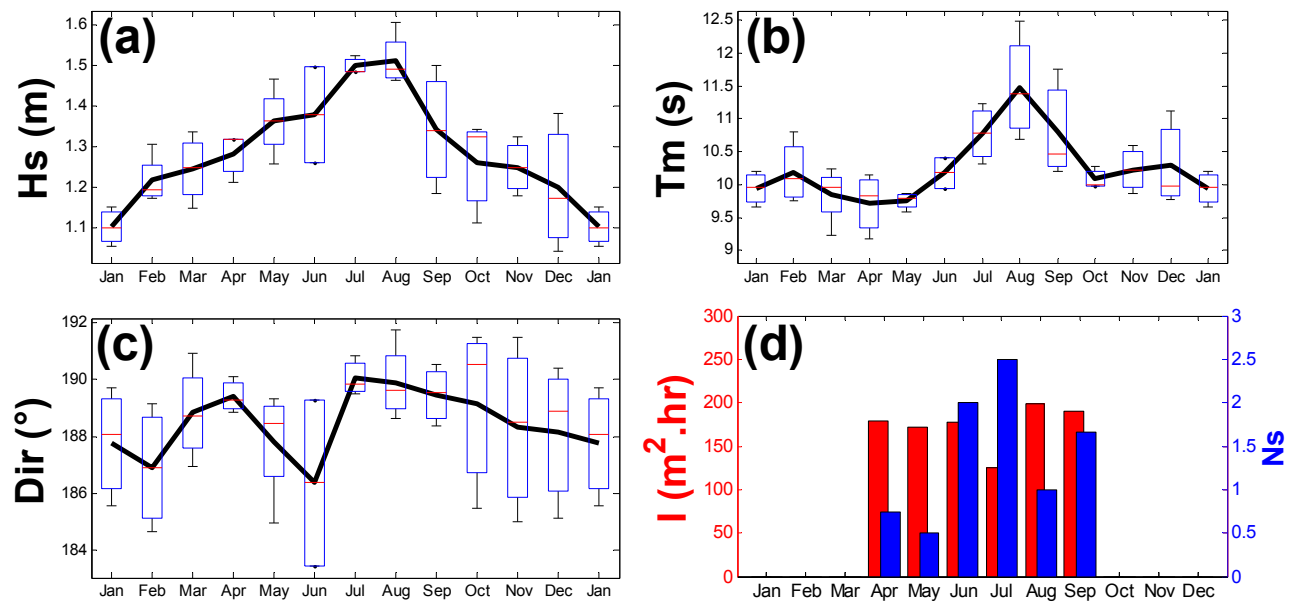

Figure 6. Seasonal variability (monthly average) of: (a) $H s,(\mathbf{b}) \mathrm{Tm}$, (c) wave direction (Dir), and (d) storm intensity in $\mathrm{m}^{2} \cdot \mathrm{h}$ (red) and storm number Ns (blue). For each box, the central mark (red line) is the median, the edges of the box (blue) are the 25th and 75th percentiles, and the whiskers extend to the most extreme data points not considered outliers. 
The seasonal cycle of the shoreline presented two main different phases, the erosive phase (January to August) and the accretive phase (August to December), due to the changes of Hs (Figure 6a) and Tm (Figure 6b), which were driven by swell waves. The standard deviation of the beach slope variation was smaller during the eroding period, reflecting the low variability of the beach slope according to low-energy waves.
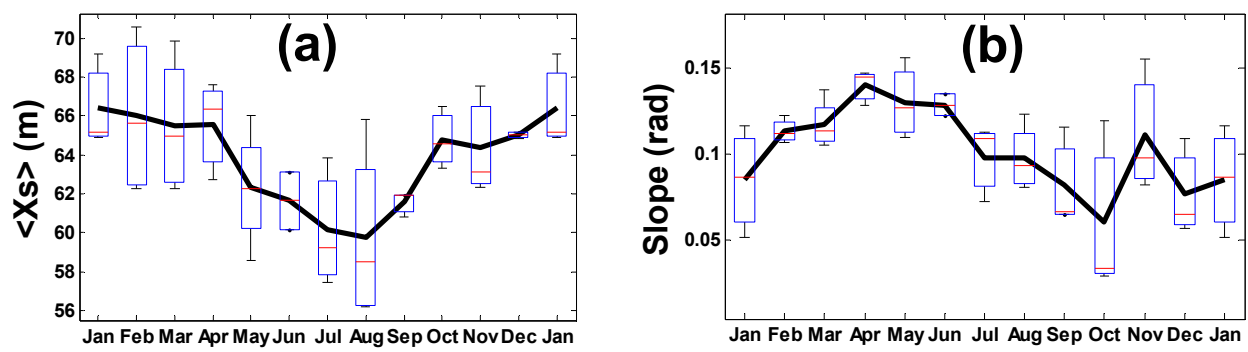

Figure 7. Monthly average seasonal variability: (a) mean shoreline location $\langle X s\rangle$ from video camera location, and (b) beach slope. For each box, the central mark (red line) is the median, the edges of the box (blue) are the 25 th and 75 th percentiles, and the whiskers extend to the most extreme data points not considered outliers.

Storms occurred at the end of the eroding period (April to July) and at the beginning of the accreting period (August to September). The beach exhibited particular responses to storm-events, depending on the concerned period, as shown in Figure 8, where only 12 storms were considered with their corresponding shoreline data. During this eroding period, the recovery duration seemed to be shorter ( $\sim 10$ days). In contrast, in the accreting period, the time recovery duration seemed to be longer and the storm impact increased with the storm duration, consistent with [17]. The post-storm recovery was more significant in the accreting period than in the eroding period. In August, the beach experienced an onshore migration of $2.4 \mathrm{~m}$ during a 1.4 day averaged-duration storm, while in September, a 3.7 day averaged-duration storm caused an erosion of $-5.4 \mathrm{~m}$. The beach response was therefore influenced by the erosive or accretive period of the wave climate oscillation.

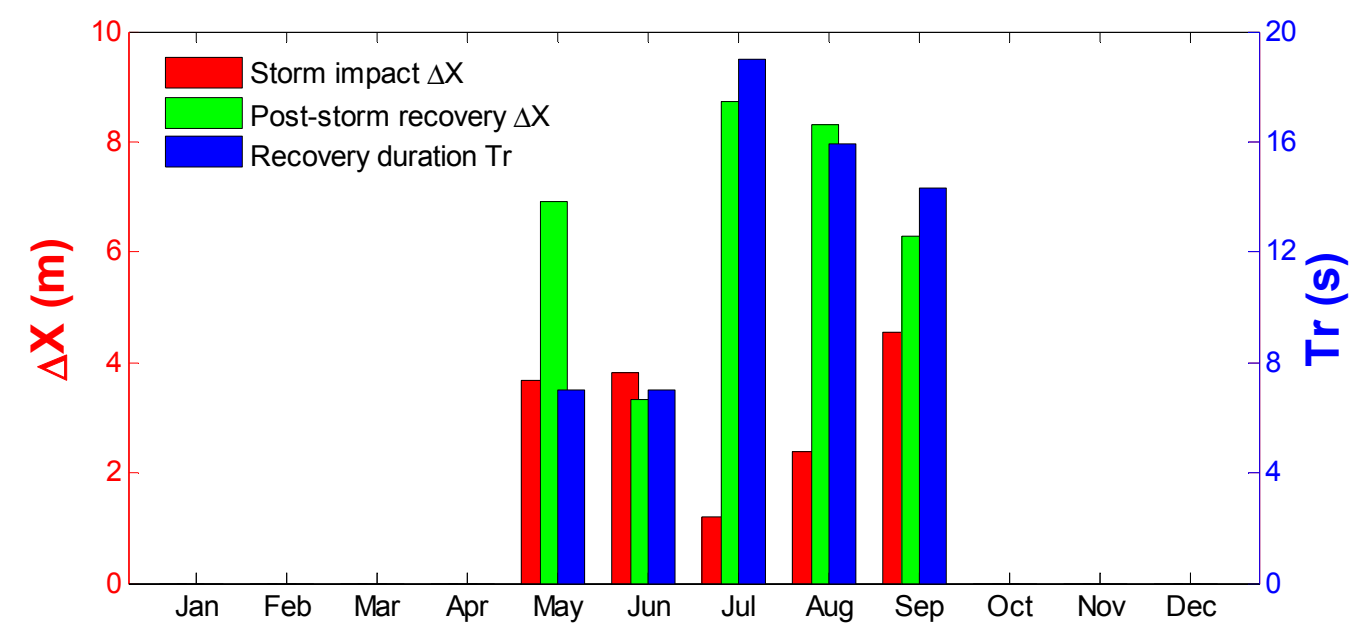

Figure 8. Ensemble-averaged shoreline variation $<\Delta X_{j}>$ during and after storm-events: storm impact (red), beach recovery (green), and recovery duration (blue) per month.

\subsection{Trends and Inter-Annual Evolution}

Trends of waves and the shoreline were investigated using the test of Mann Kendall [33]. The results showed that the shoreline position $H s$ and wave direction data presented substantial 
trends. A failure to reject the null hypothesis (absence of trend) at $95 \%$ significance level was obtained for the wave period and energy, and the beach slope. The residual signal reflected trends over the study period and was obtained by removing the seasonal cycle from the daily data. Table 2 shows the annual average and residuals of each studied parameter. During the 3.5 year study period, the shoreline migrated $6 \mathrm{~m}$ onshore. The annual anomaly or residual of the shoreline decreased from $+2.8 \mathrm{~m}$ in 2013 to $-2.9 \mathrm{~m}$ in 2016, while the annual residual of the beach slope did not change. A decrease of $3^{\circ}$ in the wave direction was observed during the study period.

Table 2. Annual averaged values and anomalies $\left(R_{a}\right)$ for the study period.

\begin{tabular}{ccccccccc}
\hline & \multicolumn{2}{c}{2013} & \multicolumn{2}{c}{2014} & \multicolumn{2}{c}{2015} & \multicolumn{2}{c}{2016} \\
Study Period & \multicolumn{2}{c}{} & \multicolumn{2}{c}{ (January-August) } \\
\cline { 2 - 10 } & Mean & $\boldsymbol{R}_{\boldsymbol{a}}$ & Mean & $\boldsymbol{R}_{\boldsymbol{a}}$ & Mean & $\boldsymbol{R}_{\boldsymbol{a}}$ & Mean & $\boldsymbol{R}_{\boldsymbol{a}}$ \\
\hline$H s(\mathrm{~m})$ & 1.35 & +0.05 & 1.34 & +0.04 & 1.23 & -0.07 & 1.28 & -0.06 \\
$\operatorname{Tm}(\mathrm{s})$ & 10.4 & +0.2 & 10.1 & -0.2 & 10.2 & -0.1 & 10.6 & +0.3 \\
$\operatorname{Dir}\left({ }^{\circ}\right)$ & 188.9 & +1.4 & 188.2 & +0.5 & 186.4 & -1.3 & 185.2 & -1.8 \\
Shoreline position (m) & 66.4 & +2.8 & 63.9 & +0.2 & 61.8 & -1.9 & 60.1 & -2.9 \\
Beach slope (rad) & 0.098 & -0.006 & 0.101 & 0 & 0.109 & +0.008 & 0.113 & -0.04 \\
\hline
\end{tabular}

\section{Discussion}

Perhaps more than other survey techniques (e.g., DGPS, LIght Detection And Ranging LIDAR) used in coastal science, the video system remains less costly. However, video measurements are subject to large uncertainties [10]. In particular, the shoreline-detection methods are sensitive to waves, lighting conditions, and water levels, which can scale the effects of both the setup and run-up, and reduce the colour signal strength [32]. Previous works on video error detection [18,23,36] compared shorelines measured by video to topographic surveys, and the results suggested a reasonable error (about $0.23 \mathrm{~m}$ at Grand Popo, Benin, following [18]). In this work, tidal heights were estimated using the WXTide2 model, to compute the shoreline location. This did not take into account all regional and coastal components of the sea level (including wave-induced setup and run-up) and nearshore bathymetry that were measured by the video [18].

The results presented here are consistent with the wave climate observations in the studied area $[14,15]$. A seasonal pattern was clearly observed in the shoreline position, beach slope, and wave characteristics. Data exhibited two specific periods: an accreting period (August to December), where $H s$ and $\mathrm{Tm}$ decreased; and an eroding period, where $H s$ and $\mathrm{Tm}$ increased (January to July). This was consistent with the oscillation of the Southern Annular Mode (SAM), which has a predominant influence on transport induced by swell waves [15]. The low values of the beach slope standard deviation observed during February to April reflected a stabilization reached during low wave-energy conditions. Computing the beach slope variability could lead to an understanding of the nature of the waves breaking, as the beach slope is connected to the surf-similarity parameter. A recent finding [20] suggested that the wave reflection is mostly governed by swash dynamics, whereby the reflected spectrum essentially depends on the swash slope.

The 3.5 years of video of the shoreline location suggests that beach dynamics observed at Grand Popo Beach are affected by storm-events. This study revealed that the impact on shoreline migration can be significant: $-8.7 \mathrm{~m}$ on 21 September 2013, during a 4 day sequence of storms. The mean duration of the 12 observed storms was 1.6 days, with an average storm-erosion of $-3.1 \mathrm{~m}$. At the end of the storm, the shoreline migrated offshore at an average distance of $6 \mathrm{~m}$ within 15 days. However, the storm impact and post-storm recovery were very dependent on the observed seasonal pattern, consistent with [17]. The recovery duration in the eroding period was shorter ( 10 days) than in the accreting period ( $>15$ days). The end of the period of stabilization observed between February and April was marked by short storms of an average duration of less than 1 day, which caused significant erosion on the beach, averaging $3.7 \mathrm{~m}$. During the accreting period, it took longer storms to observe a 
significant impact (mean of 3.7 days for $-5.4 \mathrm{~m}$ ). The beach's response was therefore mostly related to the energy of average wave conditions, rather than to the energy of extreme wave conditions.

The study of inter-annual trends in this work demonstrated a gradual decline of the shoreline cross-shore location during the period 2013-2016. However, the length of the data set was not enough to assess the inter-annual variability. A field of nine groins of $100 \mathrm{~m}$ lengths and $20 \mathrm{~m}$ widths was constructed between 2012 and 2014 over a distance of $3.5 \mathrm{~km}$, near the city of Anèho (Togo), about $20 \mathrm{~km}$ from the video system at Grand Popo Beach. This field could reduce the sediment supply of the eastward coastal drift in the direction of Grand Popo. A recent study [19] investigated the coastline evolution between Grand Popo (Benin) and Anèho (Togo) from 1984 to 2011, using Landsat TM (Thematic Mapper) and ETM+ (Enhanced Thematic Mapper Plus) images. This study showed that the locality of Grand Popo was in dynamic equilibrium from 1984 to 2000, while a significant accretion occurred with $+0.4 \mathrm{~m} /$ year between 2000 and 2011. The impact of the field of groins was also investigated, but no clear conclusions were drawn on its impacts on the coastal area of Grand Popo; although immediately downstream from the groynes, the region is experiencing significant visual erosion.

The trend of oceanic forcing (wave direction of $-3^{\circ}$ for the period 2013-2015) is another possible factor of the observed erosion. The diminution of the wave direction from $188.9^{\circ}$ to $185.2^{\circ}$ during the study period increased the importance of cross-shore processes compared to along-shore processes, resulting in a decrease in the along-shore sediment transport ( $5 \%$ per year), computed with an empirical formula [30] presented in [15], in our study area. The longshore sediment transport is very dependent on the shore's normal wave direction, and the resulting littoral drift in the Bight of Benin is one of the largest in the world, following [14,15]. Nevertheless, the video estimates of the wave direction had uncertainties. A comparison of video and WW3 wave direction outputs showed that the video data presented a larger standard deviation than the model output, respectively $13.4^{\circ}$ (video) and $6.4^{\circ}$ (WW3), and the video wave direction trend was not observed in the WW3 data. A previous study estimated the RMSE with field ADCP measurements to be about $9.25^{\circ}$, and the mean error (ME) to be $2.25^{\circ}$, within the range of observed variation from 2013 to $2016\left(-3^{\circ}\right)$.

\section{Conclusions}

Three and a half years of video-derived shoreline and wave evolution data at Grand Popo Beach was used to investigate the beach's response to wave forcing from event to inter-annual time scales in the coastal area of Grand Popo Beach, Benin. The beach exhibited a seasonal pattern in wave conditions and the along-shore-averaged shoreline position was most related to the monthly-averaged wave height rather than the average storm intensity. The seasonal pattern of the shoreline indicated an eroding period and an accreting period, corresponding to austral and winter periods, respectively. Thirty-two storms were identified for the period 2013-2016. The mean storm duration was 1.6 days for the 12 observed storms due to gaps in video data, and the average storm erosion was $-3.1 \mathrm{~m}$. Ensemble-averaged storm recovery conditions showed that the beach recovered within 15 days, and the average recovery rate was $0.4 \mathrm{~m} /$ day. This study underlines that the impact of storms is more or less amplified depending on the eroding and accreting periods of the wave climate: (i) the recovery duration is longer in the accreting period than in the eroding period, (ii) the storm-impact is more significant in the eroding period than in the accreting period, (iii) storms are longer in the accreting period than in the eroding period, and (iv) storm numbers are high during the transition from the eroding to accretive phases. A trend on the along-shore-averaged shoreline location was observed $(-1.6 \mathrm{~m} /$ year $)$, however our data were not enough to draw conclusions at inter-annual time scales.

Acknowledgments: This publication was made possible through support provided by the IRD. We acknowledge the use of the WW3 dataset (IOWAGA wave hindcast database; http:/ /tds1.ifremer.fr/thredds/IOWAGA-WW3HINDCAST). We would like to express our gratitude to IRD/JEAI-RELIFOME (Jeune Equipe Associée à l'IRD) for its financial support and to support the three months stay at Gao in Benin. Thanks are due to Gaël ALory for his technical support in maintaining the video system. The Grand Popo experiment was supported by the French INSU/CNRS EC2CO-LEFE/IRD, UNESCO Co-Chair ICMPA/UAC. We are indebted to the "Forces Navales" 
of Benin at Grand Popo for their logistic support during field experiments and for allowing the installation of the permanent video system on the semaphore. This work was supported by French ANR project COASTVAR (ANR-14-ASTR-0019).

Author Contributions: All authors were implicated in maintaining the video system at Grand Popo and analysis of data.

Conflicts of Interest: The authors declare no conflict of interest.

\section{References}

1. Stive, M.J.F.; Aarninkhof, S.G.J.; Hamm, L.; Hanson, H.; Larson, M.; Wijnberg, K.M.; Nicholls, R.J.; Capobianco, M. Variability of shore and shoreline evolution. Coast. Eng. 2002, 47, 211-235. [CrossRef]

2. Ranasinghe, R.; Callaghan, D.; Stive, M.J.F. Estimating coastal recession due to sea level rise: Beyond the Bruun rule. Clim. Chang. 2012, 110, 561-574. [CrossRef]

3. Ruggiero, P.; Cote, J.; Kaminsky, G.; Gelfenbaum, G. Scales of variability along the Columbia River littoral cell. In Proceedings of the Coastal Sediments '99: The 4th International Symposium on Coastal Engineering and Science of Coastal Sediment Processes, Hauppauge, NY, USA, 21-23 June 1999; pp. 1692-1707.

4. Brunel, C.; Sabatier, F. Potential influence of sea-level rise in controlling shoreline position on the French Mediterranean Coast. Geomorphology 2009, 107, 47-57. [CrossRef]

5. Senechal, N.; Coco, G.; Castelle, B.; Marieu, V. Storm impact on the seasonal shoreline dynamics of a meso-to macrotidal open sandy beach (Biscarrosse, France). Geomorphology 2015, 228, 448-461. [CrossRef]

6. Zhang, K.; Douglas, B.; Leatherman, S. Do storms cause long-term beach erosion along the U.S. East Barrier Coast? J. Geol. 2002, 110, 493-502. [CrossRef]

7. Morton, R.A.; Paine, J.G.; Gibeaut, J.G. Stages and durations of post-storm beach recovery, southeastern Texas coast, USA. J. Coast. Res. 1994, 10, 884-908.

8. Morton, R.A.; Gibeaut, J.C.; Paine, J.G. Meso-scale transfer of sand during and after storms: Implications for prediction of shoreline movement. Mar. Geol. 1995, 126, 161-179. [CrossRef]

9. Castelle, B.; Marieu, V.; Bujan, S.; Splinter, K.D.; Robinet, A.; Senechal, N.J.; Ferreira, S. Impact of the winter 2013-2014 series of severe Western Europe storms on a double-barred sandy coast: Beach and dune erosion and megacusp embayments. Geomorphology 2015, 238, 135-148. [CrossRef]

10. Masselink, G.; Scott, T.; Russel, P.; Davidson, M.A.; Conley, D.C. The extreme 2013/2014 winter storms: Hydrodynamic forcing and coastal response along the southwest coast of England. Earth Surf. Process. Landf. 2015, 41, 378-391. [CrossRef]

11. Almeida, L.P.; Vousdoukas, M.V.; Ferreira, Ó.; Rodrigues, B.A.; Matias, A. Thresholds for storm impacts on an exposed sandy coastal area in southern Portugal. Geomorphology 2012, 143, 3-12. [CrossRef]

12. Angnuureng, D.B.; Almar, R.; Senechal, N.; Castelle, B.; Addo, K.A.; Marieu, V.; Ranasinghe, R. Shoreline resilience to individual storms and storm clusters on a meso-macrotidal barred beach. Geomorphology 2017, 290, 265-276. [CrossRef]

13. Ba, A.; Senechal, N. Extreme winter storm versus summer storm: Morphological impact on a sandy beach. J. Coast. Res. 2013, 1, 648-653. [CrossRef]

14. Laibi, R.; Anthony, E.; Almar, R.; Castelle, B.; Senechal, N.; Kestenare, E. Longshore drift cell development on the human-impacted Bight of Benin sand barrier coast, West Africa. J. Coast. Res. 2014, 70, 78-83. [CrossRef]

15. Almar, R.; Kestenare, E.; Reyns, J.; Jouanno, J.; Anthony, E.J.; Laibi, R.; Hemer, M.; Du Penhoat, Y.; Ranasinghe, R. Response of the Bight of Benin (Gulf of Guinea, West Africa) coastline to anthropogenic and natural forcing, Part1: Wave climate variability and impacts on the longshore sediment transport. Cont. Shelf Res. 2015, 110, 48-59. [CrossRef]

16. Anthony, E.J.; Blivi, A.B. Morphosedimentary evolution of a delta-sourced, drift-aligned sand barrier-lagoon complex, western Bight of Benin western Bight of Benin. Mar. Geol. 1999, 158, 161-176. [CrossRef]

17. Yates, M.L.; Guza, R.T.; O'Reilly, W.C. Equilibrium shoreline response: Observations and modeling. Geophys. Res. 2009, 114. [CrossRef]

18. Abessolo, O.G.; Almar, R.; Kestenare, E.; Bahini, A.; Houngue, G.H.; Jouanno, J.; Du Penhoat, Y.; Castelle, B.; Melet, A.; Meyssignac, B.; et al. Potential of video cameras in assessing event and seasonal coastline behaviour: Grand Popo, Benin (Gulf of Guinea). J. Coast. Res. 2016, 442-446. [CrossRef] 
19. Degbe, C.G.E.; Laibi, R.; Sohou, Z.; Oyede, M.L.; Du Penhoat, Y.; Djara, M.B. Diachronic analysis of coastline evolution between Grand-Popo and Hillacondji (Benin), from 1984 to 2011. Water 2016, submitted.

20. Almar, R.; Ibaceta, R.; Blenkinsopp, C.; Catalan, P.; Cienfuegos, R.; Viet, N.T.; Duong Hai, T.; Uu, D.V.; Lefebvre, J.P.; Laryea, W.S.; et al. Swash-based wave energy reflection on natural Beaches. In Proceedings of the Coastal Sediments 2015, San Diego, CA, USA, 11-15 May 2015.

21. Wright, L.D.; Short, A.D. Morphodynamic variability of surf zones and beaches: A synthesis. Mar. Geol. 1984, 56, 93-118. [CrossRef]

22. Almar, R.; Honkonnou, N.; Anthony, E.J.; Castelle, B.; Senechal, N.; Laibi, R.; Mensah-Senoo, T.; Degbe, G.; Quenum, M.; Dorel, M.; et al. The Grand Popo beach 2013 experiment, Benin, West Africa: From short timescale processes to their integrated impact over long-term coastal evolution. J. Coast. Res. 2014, 651-656. [CrossRef]

23. Angnuureng, D.B.; Almar, R.; Addo, K.A.; Castelle, B.; Senechal, N.; Laryea, S.W.; Wiafe, G. Video observation of waves and shoreline change on the Microtidal James Town Beach in Ghana. J. Coast. Res. 2016, 1022-1026. [CrossRef]

24. Holland, K.T.; Holman, R.A.; Lippmann, T.C. Practical use of video imagery in near-shore oceanographic field studies. IEEE J. Ocean. Eng. 1997, 22, 81-92. [CrossRef]

25. Almar, R.; Ranasinghe, R.; Senechal, N.; Bonneton, P.; Roelvink, D.; Bryan, K.; Marieu, V.; Parisot, J.P. Video-based detection of shorelines at Complex Meso-Macro Tidal Beaches. J. Coast. Res. 2012, 28, 1040-1048. [CrossRef]

26. Almar, R.; Cienfuegos, R.; Catalán, P.A.; Michallet, H.; Castelle, B.; Bonneton, P.; Marieu, V. A new breaking wave height direct estimator from video imagery. Coast. Eng. 2012, 61, 42-48. [CrossRef]

27. Almar, R.; Senechal, N.; Bonneton, P.; Roelvink, D. Wave celerity from video imaging: A new method. Proceedings of Coastal Engineering 2008, Hamburg, Germany, 31 August-5 September 2008; pp. 661-673.

28. Almar, R.; Michallet, H.; Cienfuegos, R.; Bonneton, P.; Ruessink, B.G.; Tissier, M. On the use of the radon transform in studying nearshore wave dynamics. Coast. Eng. 2014, 92, 24-30. [CrossRef]

29. Rascle, N.; Ardhuin, F. Global wave parameter data base for geophysical applications. Part II: Model validation with improves source term parameterization. Ocean Model. 2013, 70, 145-151. [CrossRef]

30. Larson, M.; Hoan, L.X.; Hanson, H. Direct formula to compute wave height and angle at incipient breaking. J. Waterw. Port Coast. Ocean Eng. 2010, 136, 119-122. [CrossRef]

31. Boak, E.H.; Turner, I.L. Shoreline definition and detection: A review. J. Coast. Res. 2005, 21, 688-703. [CrossRef]

32. Aarninkhof, S.G.J.; Turner, I.L.; Dronkers, D.T.; Caljouw, M.; Nipius, L. A video-based technique for mapping intertidal beach bathymetry. Coast. Eng. 2003, 49, 275-289. [CrossRef]

33. Hamed, K.H.; Rao, A.R. A modified Mann-Kendall trend test for autocorrelated data. J. Hydrol. 1998, 204, 182-196. [CrossRef]

34. Tolman, H.L. Limiters in third-generation wind wave models. Glob. Atmos. Ocean Syst. 2002, 8, 67-83. [CrossRef]

35. Woodcock, F.; Greenslade, D.J.M. Consensus of numerical model forecasts of significant wave heights. Weather Forecast. 2007, 22, 792-803. [CrossRef]

36. Ranasinghe, R.; Holman, R.; de Schipper, M.A.; Lippmann, T.; Wehof, J.; Minh Duong, T.; Roelvink, D.; Stive, M.J.F. Quantification of nearshore morphological recovery time scales using Argus video imaging: Palm Beach, Sydney and Duck, NC. Coast. Eng. Proc. 2012, 1, 24.

(C) 2017 by the authors. Licensee MDPI, Basel, Switzerland. This article is an open access article distributed under the terms and conditions of the Creative Commons Attribution (CC BY) license (http://creativecommons.org/licenses/by/4.0/). 